Fry, B. A. (1957). J. gen. Microbiol. 16, 341-349

\title{
Basic Triphenylmethane Dyes and the Inhibition of Glutamine Synthesis by Staphylococcus aureus
}

\author{
By B. A. FRY \\ Medical Research Council Unit for Chemical Microbiology, University of Cambridge \\ and Department of Microbiology, University of Sheffield*
}

SUMMARY: Glutamine synthesis by Staphylococcus aureus is inhibited by the basic triphenylmethane dyes crystal violet, methyl green, fuchsin, pararosaniline, brilliant green and malachite green. In the $\mathrm{pH}$ range $6 \cdot 5-8 \cdot 5$, the inhibitory action of crystal violet is independent of $\mathbf{p H}$, whilst with fuchsin, brilliant green and malachite green, the degree of inhibition is increased by increasing the hydrogen ion concentration of the medium. At pH 7.5, inhibitory activity increases in the order: brilliant green, fuchsin, malachite green, methyl green, crystal violet. The effectiveness of a basic triphenylmethane dye as an inhibitor of glutamine synthesis can be correlated with the basic dissociation constant of the dye.

During studies of the effects of various antibacterial agents on the uptake of glutamic acid by Streptococcus faecalis Gale \& Mitchell (1947) found that certain basic triphenylmethane dyes, e.g. crystal violet, caused an increased accumulation of the amino acid inside the cells. Since the dyes did not affect the rate at which glutamic acid passed into the cells, the increased accumulation was apparently due to the inhibition of a metabolic pathway which normally decreases the cell's content of free glutamic acid. Crystal violet does not inhibit the deamination or transamination of this amino acid, nor its incorporation into peptides or proteins (Gale \& Mitchell, 1947). During a search for enzyme systems which were inhibited by crystal violet, Elliott \& Gale (1948) found that this dye inhibited the synthesis of glutamylhydroxamic acid by cell-free extracts of Staphylococcus aureus. Glutamylhydroxamic acid is formed when the enzyme preparation is incubated with hydroxylamine, L-glutamic acid, magnesium or manganese ions, and adenosinetriphosphate (Elliott \& Gale, 1948). When the hydroxylamine is replaced by ammonia, the product of the reaction is glutamine (Fry, 1955). The work now described is a study of the effects of various triphenylmethane dyes on glutamine synthesis by cell-free extracts of $S$. aureus and an attempt to correlate their inhibitory properties with the basic dissociation constants of the dyes. A preliminary account of these experiments has been given previously (Fry, 1949).

The basic triphenylmethane dyes can exist in the form of coloured cations (as in the acid salts) or as undissociated bases, the carbinols (Fig. 1). The percentage of the dye in the cationic state is therefore dependent on the hydrogenion concentration of the system, and the greater the hydrogen-ion concentration, the greater the dissociation into the cationic form. Experiments with such dyes are complicated by two of their inherent properties. First, the 
equilibrium between the cation and the carbinol often requires an appreciable time to become established; and secondly, the carbinol form is relatively insoluble (Goldacre \& Phillips, 1949).

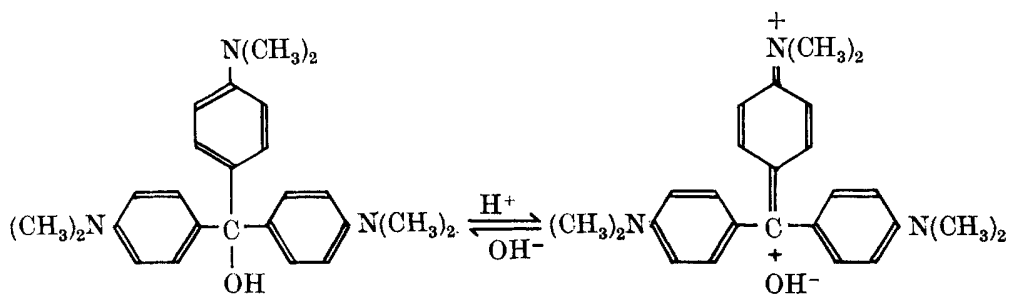

Fig. 1. The dissociation of crystal violet.

\section{METHODS}

Organism, growth medium, preparation of cell-free extracts. Staphylococcus aureus strain Duncan(Medical Research Council Unit for Chemical Microbiology, University of Cambridge) was grown at $37^{\circ}$ for $6 \mathrm{hr}$. on a medium of initial $\mathrm{pH} 7.0$ and containing $3 \%(\mathrm{v} / \mathrm{v})$ tryptic or papain digest of casein (i.e. the equivalent of $3 \mathrm{~g}$. digested casein $/ 100 \mathrm{ml}$.), $0 \cdot 1 \%(\mathrm{w} / \mathrm{v})$ Marmite and $1 \%(\mathrm{w} / \mathrm{v})$ glucose. The medium was dispensed in Roux bottles (150 ml./bottle). The organism was subcultured at $37^{\circ}$ in test tubes containing $5 \mathrm{ml}$. of the same medium, and $0.5 \mathrm{ml}$. of a $16 \mathrm{hr}$. subculture was used to inoculate each Roux bottle. The organism was harvested by centrifuging, washed once with distilled water and then suspended in distilled water at a concentration equivalent to $30 \mathrm{mg}$. dry wt./ml. (for dry wt. determinations see Fry, 1955). The suspension was shaken with glass beads (Chance Bros. Ballotini no. 14) $10 \mathrm{~g}$./tube, in a Mickle disintegrator (Mickle, 1948). After removing the beads by filtration, the filtrate was centrifuged at $1000 \mathrm{~g}$ for $30 \mathrm{~min}$. The clear yellowish cell-free supernatant fluid was decanted from the debris and is the enzyme preparation used in all the reported experiments.

Chemicals. L-Glutamic acid (L. Light and Co. Ltd., Colnbrook, Bucks) was recrystallized as the hydrochloride. Adenosine triphosphate (ATP) was prepared from rabbit muscle (LePage, 1949) as the monobarium salt and solutions of the sodium salt were stored at $-10^{\circ}$ (Bailey, 1949). The glyoxaline buffers (Kirby \& Neuberger, 1938) were prepared from the appropriate base hydrochlorides (British Drug Houses Ltd., London) and NaOH.

Dyes. Crystal violet was supplied by Hopkins and Williams Ltd., brilliant green, malachite green, fuchsin, methyl green, and pararosaniline by G. T. Gurr Ltd., and aurine by Imperial Chemical Industries. Crystal violet was recrystallized twice from hot water (Vogel, 1948); brilliant green and malachite green were purified by the methods of Lewis, Magel \& Lipkin (1942). Dyes were added to the experimental systems in the form of an aqueous solution of their acid salts. The percentage of the dye in the cationic state was estimated colorimetrically (Goldacre \& Phillips, 1949). 


\section{Analytical methods}

Glutamine. Glutamine was estimated in terms of the ammonia liberated by hydrolysis with $5 \%(\mathrm{w} / \mathrm{v}) \mathrm{H}_{2} \mathrm{SO}_{4}$ at $100^{\circ}$ for $10 \mathrm{~min}$. (Krebs, 1935). The procedure for the distillation of ammonia in the Parnas apparatus (Parnas \& Heller, 1924) and its subsequent estimation by titration was the same as previously described (Fry, 1955).

Glutamylhydroxamic acid. Glutamylhydroxamic acid was determined colorimetrically by a method (Elliott, 1948) based on that developed by Lipmann \& Tuttle $(1945 a, b)$ using synthetic glutamylhydroxamic acid as standard and a Hilger Spekker absorptiometer with a green filter (Ilford no. 604 with peak transmission at $520 \mathrm{~m} \mu$.).

\section{Standard experimental systems}

The standard experimental systems for studying the synthesis of glutamine consisted of $1 \mathrm{ml}$. enzyme preparation, $0.04 \mathrm{M}-4(5)$-methylglyoxaline buffer pH 7.5, 0.01 $\mathrm{M}-\mathrm{MgCl}_{2}, 0.1 \mathrm{M}$ sodium L-glutamate, $14.3 \mu$ mole $\mathrm{NH}_{4} \mathrm{Cl}$ and $0.006 \mathrm{M}$-ATP in a total volume of $4.5 \mathrm{ml}$. Control systems did not contain added glutamate. Experimental systems were incubated in open test tubes in a water bath at $37^{\circ}$ and the reaction was started by the addition of ATP after the tubes had been in the bath for $10 \mathrm{~min}$. Where synthesis of glutamylhydroxamic acid was required, the $\mathrm{NH}_{4} \mathrm{Cl}$ was replaced by $0 \cdot 4 \mathrm{M}$-hydroxylamine (Fry, 1955).

Results. Where applicable, results are expressed in terms of $\mu$ mole amidenitrogen/total volume $(4.5 \mathrm{ml}$.) of experimental system.

\section{RESULTS}

\section{Inhibition of glutamine synthesis by crystal violet and methyl green}

Elliott \& Gale (1948) found that crystal violet at $2.5 \times 10^{-4} \mathrm{M}$ inhibited the synthesis of glutamylhydroxamic acid. Preliminary experiments were therefore performed to determine the range of concentrations in which crystal violet exhibited any inhibitory action on glutamine synthesis. In these experiments, as in those of Elliott \& Gale, the dye was added to the standard experimental systems a short time (less than $10 \mathrm{~min}$.) before the enzyme preparation, and no account was taken of the fact that time might be required to establish an equilibrium between the cationic form and the carbinol of the dye. Concentrations of crystal violet greater than $6 \cdot 2 \times 10^{-5} \mathrm{M}$ produced progressive inhibition of glutamine synthesis (Fig. 2). Similar experiments were later performed with methyl green, and the inhibitory activity of this dye was found to be comparable with that of crystal violet (Fig. 2). Brilliant green, malachite green, pararosaniline and fuchsin were not as effective as crystal violet or methyl green. For example, whereas crystal violet at $1 \cdot 2 \times 10^{-4} \mathrm{M}$ produced $50 \%$ inhibition, concentrations of the order $7 \times 10^{-4} \mathrm{M}$ of these four dyes were required to produce the same degree of inhibition. 


\section{Effect of $\mathrm{pH}$ value on the inhibitory activity of basic triphenylmethane dyes}

The dyes selected for the study of inhibitory activity as a function of hydrogen-ion concentration were crystal violet, brilliant green, fuchsin and malachite green; the basic dissociation constants (pK) of these dyes have been determined by Goldacre, Phillips and other workers (Goldacre \& Phillips, 1949). With dyes such as crystal violet, methyl green and fuchsin, the equilibrium between the cation and carbinol can be established in the standard

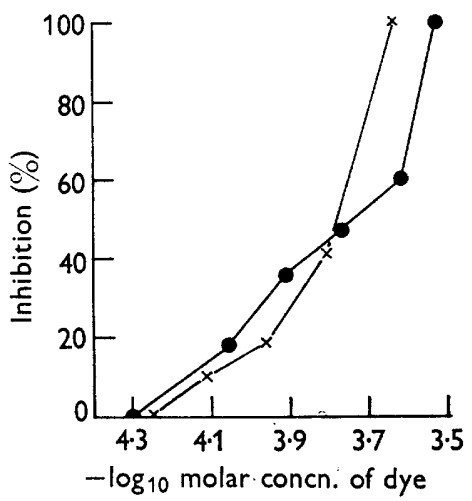

Fig. 2

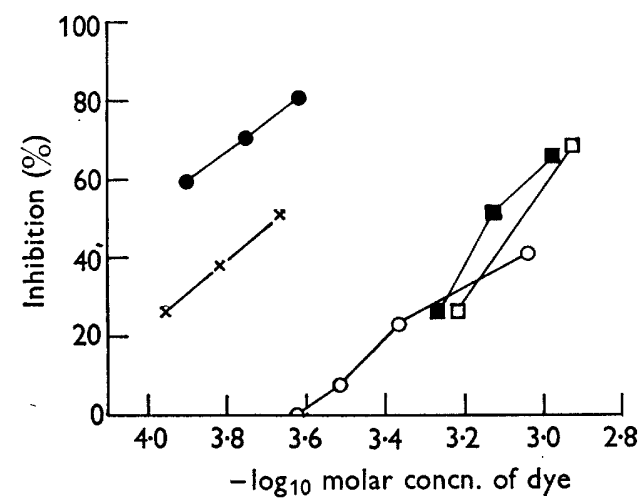

Fig. 3

Fig. 2. Inhibition of glutamine synthesis by crystal violet and methyl green. Complete and control systems : the standard experimental systems (see Methods, p. 343) with crystal violet $(\Theta)$ or methyl green $(x)$ added to both as required. Incubated $1 \mathrm{hr}$. at $37^{\circ}$. Values in controls subtracted. Results compared with synthesis in the absence of dye and expressed as \% inhibition. (Enzyme preparation in crystal violet experiments different from that used in methyl green experiments.)

Fig. 3. Inhibition of glutamine synthesis by crystal violet $(\Theta)$, methyl green $(x)$, fuchsin $(\square)$, malachite green $(\square)$ and brilliant green $(O)$. Complete and control systems : the standard experimental systems (see Methods, p. 343) with dye added to both as required $1 \mathrm{hr}$. before the addition of enzyme and ATP $(8 \mathrm{hr}$. in the case of crystal violet). Incubated $1 \mathrm{hr}$. at $37^{\circ}$. Values in controls subtracted. Results compared with synthesis in the absence of dye and expressed as \% inhibition. Same enzyme preparation used in all experiments.

experimental systems without precipitation of the carbinol. But the concentrations of brilliant green and malachite green which were required in these experiments were such that at certain hydrogen-ion concentrations the carbinol form began to precipitate. In these circumstances a true equilibrium could not be established.

The same enzyme preparation was used throughout the experiment and glutamine synthesis in different conditions of hydrogen-ion concentration was compared with that in the presence of known concentrations of the four dyes being studied. The dyes were incubated in duplicate experimental systems at $37^{\circ}$ before the addition of the enzyme and ATP in order that conversion of the cationic form to the carbinol could take place. Samples from one set of experimental systems were used to estimate the amount of the dye in the 
cationic state at the time when the enzyme preparation and ATP were added to the other set used to determine glutamine synthesis. The equilibration period allowed in the crystal violet experiment was $8 \mathrm{hr}$., since the equilibrium between cation and carbinol is established slowly (Goldacre \& Phillips, 1949).

Table 1. Effect of $\mathrm{pH}$ value on the inhibition of glutamine synthesis in Staphylococcus aureus by basic triphenylmethane dyes

Complete and control systems: the standard experimental systems (see Methods, p. 343) with dye added to both as required. Incubated $1 \mathrm{hr}$. at $37^{\circ} . \%$ of dye as cation is the \% of dye in the cationic state when enzyme preparation added. Dye incubated at $37^{\circ}$ in experimental systems before addition of enzyme preparation: crystal violet, for $8 \mathrm{hr}$; fuchsin, malachite green and brilliant green, for $1 \mathrm{hr}$. Different enzyme preparation for each dye.

\begin{tabular}{|c|c|c|c|c|c|c|c|c|c|}
\hline \multirow[t]{2}{*}{ 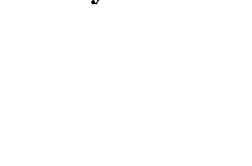 } & & \multicolumn{3}{|c|}{ No dye } & \multicolumn{3}{|c|}{ Dye added } & \multirow{3}{*}{$\begin{array}{l}\text { Inhibi- } \\
\text { tion } \\
(\%)\end{array}$} & \multirow{3}{*}{$\begin{array}{c}\text { Propor- } \\
\text { tion of } \\
\text { dye as } \\
\text { cation } \\
(\%)\end{array}$} \\
\hline & & $\begin{array}{l}\text { Control } \\
\quad(A)\end{array}$ & $\begin{array}{c}\text { Complete } \\
\text { system } \\
(B)\end{array}$ & $\begin{array}{c}\text { Activity } \\
(B-A)\end{array}$ & $\begin{array}{l}\text { Control } \\
(C)\end{array}$ & $\begin{array}{l}\text { Complete } \\
\text { system } \\
(D)\end{array}$ & $\begin{array}{c}\text { Activity } \\
(D-C)\end{array}$ & & \\
\hline Dye & $\mathbf{p H}$ & \multicolumn{6}{|c|}{ Amide nitrogen $(\mu$ mole $)$} & & \\
\hline $\begin{array}{l}\text { Crystal violet, } \\
1 \cdot 2 \times 10^{-4} \mathrm{M}\end{array}$ & $\begin{array}{l}8 \cdot 5 \\
8 \cdot 0 \\
7 \cdot 5 \\
7 \cdot 0 \\
6 \cdot 5\end{array}$ & $\begin{array}{l}0.5 \\
0.5 \\
0.5 \\
0.5 \\
0.5\end{array}$ & $\begin{array}{l}3 \cdot 6 \\
3 \cdot 6 \\
3 \cdot 8 \\
3 \cdot 5 \\
2 \cdot 9\end{array}$ & $\begin{array}{l}3 \cdot 1 \\
3 \cdot 1 \\
3 \cdot 3 \\
3 \cdot 0 \\
2 \cdot 4\end{array}$ & $\begin{array}{l}0 \cdot 5 \\
0.5 \\
0.5 \\
0.5 \\
0.5\end{array}$ & $\begin{array}{l}1 \cdot 8 \\
1 \cdot 9 \\
1 \cdot 8 \\
1 \cdot 7 \\
1 \cdot 5\end{array}$ & $\begin{array}{l}1 \cdot 3 \\
1 \cdot 4 \\
1 \cdot 3 \\
1 \cdot 2 \\
1 \cdot 0\end{array}$ & $\begin{array}{l}58 \\
55 \\
61 \\
60 \\
58\end{array}$ & $\begin{array}{l}100 \\
100 \\
100 \\
100 \\
100\end{array}$ \\
\hline Fuchsin, $1 \times 10^{-3} \mathrm{M}$ & $\begin{array}{l}8 \cdot 0 \\
7 \cdot 5 \\
7 \cdot 0 \\
6 \cdot 5\end{array}$ & $\begin{array}{l}0 \cdot 3 \\
0 \cdot 3 \\
0 \cdot 3 \\
0 \cdot 3\end{array}$ & $\begin{array}{l}4 \cdot 5 \\
4 \cdot 6 \\
4 \cdot 2 \\
3 \cdot 1\end{array}$ & $\begin{array}{l}4 \cdot 2 \\
4 \cdot 3 \\
3 \cdot 9 \\
2 \cdot 8\end{array}$ & $\begin{array}{l}0 \cdot 3 \\
0 \cdot 3 \\
0 \cdot 3 \\
0 \cdot 3\end{array}$ & $\begin{array}{l}3 \cdot 8 \\
3 \cdot 9 \\
2 \cdot 7 \\
0 \cdot 9\end{array}$ & $\begin{array}{l}3 \cdot 5 \\
3 \cdot 6 \\
2 \cdot 4 \\
0 \cdot 6\end{array}$ & $\begin{array}{l}17 \\
16 \\
39 \\
79\end{array}$ & $\begin{array}{l}10 \\
10 \\
24 \\
52\end{array}$ \\
\hline $\begin{array}{l}\text { Malachite green, } \\
7 \cdot 6 \times 10^{-4} \mathrm{M}\end{array}$ & $\begin{array}{l}8 \cdot 0 \\
7 \cdot 5 \\
7 \cdot 0 \\
6 \cdot 5\end{array}$ & $\begin{array}{l}0 \cdot 3 \\
0 \cdot 3 \\
0 \cdot 3 \\
0 \cdot 3\end{array}$ & $\begin{array}{l}3 \cdot 5 \\
3 \cdot 5 \\
3 \cdot 0 \\
2 \cdot 6\end{array}$ & $\begin{array}{l}3 \cdot 2 \\
3 \cdot 2 \\
2 \cdot 7 \\
2 \cdot 3\end{array}$ & $\begin{array}{l}0 \cdot 3 \\
0 \cdot 3 \\
0 \cdot 3 \\
0 \cdot 3\end{array}$ & $\begin{array}{l}2 \cdot 8 \\
2 \cdot 6 \\
1 \cdot 6 \\
1 \cdot 1\end{array}$ & $\begin{array}{l}2 \cdot 5 \\
2 \cdot 3 \\
1 \cdot 3 \\
0 \cdot 8\end{array}$ & $\begin{array}{l}22 \\
28 \\
52 \\
65\end{array}$ & $\begin{array}{r}8 \\
8 \\
26 \\
36\end{array}$ \\
\hline $\begin{array}{l}\text { Brilliant green, } \\
8.8 \times 10^{-4} \mathrm{M}\end{array}$ & $\begin{array}{l}8 \cdot 0 \\
7 \cdot 5 \\
7 \cdot 0 \\
6 \cdot 5\end{array}$ & $\begin{array}{l}0 \cdot 4 \\
0 \cdot 4 \\
0 \cdot 4 \\
0 \cdot 4\end{array}$ & $\begin{array}{l}4 \cdot 1 \\
4 \cdot 2 \\
3 \cdot 6 \\
3 \cdot 1\end{array}$ & $\begin{array}{l}3 \cdot 7 \\
3 \cdot 8 \\
3 \cdot 2 \\
2 \cdot 7\end{array}$ & $\begin{array}{l}0.4 \\
0.4 \\
0.4 \\
0.4\end{array}$ & $\begin{array}{l}3 \cdot 7 \\
3 \cdot 7 \\
3 \cdot 0 \\
1 \cdot 9\end{array}$ & $\begin{array}{l}3 \cdot 3 \\
3 \cdot 3 \\
2 \cdot 6 \\
1 \cdot 5\end{array}$ & $\begin{array}{l}14 \\
13 \\
19 \\
44\end{array}$ & $\begin{array}{r}6 \\
11 \\
18 \\
29\end{array}$ \\
\hline
\end{tabular}

In the $\mathrm{pH}$ range $6 \cdot 5-8 \cdot 5$, the dye was $100 \%$ dissociated and the percentage inhibition due to $1.2 \times 10^{-4} \mathrm{M}$ crystal violet was not affected by change in $\mathrm{pH}$ value (Table 1). With fuchsin, the equilibrium was established within $1 \mathrm{hr}$., and with malachite green and brilliant green, because of precipitation of the carbinol, the 'equilibration' period was arbitrarily fixed at $1 \mathrm{hr}$. An increase in the hydrogen-ion concentration of the system was accompanied by an increase in the percentage inhibition of glutamine synthesis by fuchsin, malachite green and brilliant green (Table 1). The amounts of these three dyes in the cationic form increased with increase in the hydrogen-ion concentration of the system, and this result was not unexpected since the $\mathrm{pK}$ values for fuchsin, malachite green and brilliant green are $c .7 \cdot 0,6 \cdot 9$ and $7 \cdot 9$, respectively (Goldacre \& Phillips, 1949). There would thus appear to be a correlation between percentage inhibition and the degree of dissociation of the dye. If this were true, then the order of effectiveness of the dyes at a given $\mathrm{pH}$ value should be 
related to the values of their basic dissociation constants. The effect of five dyes at $\mathrm{pH} 7.5$ was determined and when activity is expressed in terms of the concentration producing $50 \%$ inhibition, then the following order of increasing effectiveness was found: brilliant green, fuchsin, malachite green, methyl green, crystal violet (Fig. 3). The dyes fell into two groups: crystal violet and methyl green were the most active inhibitors of glutamic synthesis, and malachite green, fuchsin and brilliant green were about half as effective. The $\mathrm{pK}$ of crystal violet is $\mathbf{9 \cdot 3}$ and though the $\mathrm{pK}$ of methyl green has not been determined, it is probably of the same order because of the quaternary nitrogen structure of the dye (see Kligler, 1918; Gale \& Mitchell, 1947). The pK values of the other three dyes are in the range $7-8$, consequently at $\mathrm{pH} 7 \cdot 5$, crystal violet and methyl green are mostly, if not completely, dissociated, whereas the other three dyes are about $50 \%$ or less dissociated into the cationic form. It is therefore concluded that the inhibition of glutamine synthesis by the basic triphenylmethane dyes is due to the cations of the dyes and that for each dye the degree of activity is related to the dissociation constant of the equilibrium between the carbinol and cation of the dye.

The dyes used in all the above experiments were basic and for comparison, the effect of an acidic triphenylmethane dye, aurine, was determined. The synthesis of glutamylhydroxamic acid by cell-free extracts of Staphylococcus aureus was not affected by concentrations of aurine up to $5 \times 10^{-4} \mathrm{M}$ (this is twenty times the concentration of crystal violet which produced complete inhibition with the same enzyme preparation). Though aurine inhibits the internal metabolism of glutamic acid in Streptococcus faecalis, this result supports the view of Gale \& Mitchell (1947) that the mode of action of aurine is different from that of the basic triphenylmethane dyes.

\section{DISCUSSION}

The results reported here lead to the conclusion that it is in the form of their cations that the basic triphenylmethane dyes inhibit glutamine synthesis. The inhibitory effects are therefore presumably due to combination of the dye cations with negatively-charged groups in the enzyme system, either those present in the enzyme proteins or perhaps in a co-factor. The importance of thiol groups in the synthesis of glutamine in Staphylococcus aureus has already been established (Fry, 1955) though whether or not they are protein in nature, or present in a coenzyme such as coenzyme A, has not been established. In the range of hydrogen-ion concentration used in these experiments, the thiol groups would be negatively charged; it is therefore possible that such groups would attract the positively charged ions of the dye and thus form an addition complex which is not easily dissociated. In such circumstances, it is to be expected that the activity of the enzyme would be decreased. Alternatively, the dye cations may be attracted to any negatively-charged groups in the enzymic system and by steric hindrance make it impossible for the substrates to reach the appropriate receptor areas on the enzyme. Another way in which the dyes might exert their effects is by occupying the position of the 
normal cationic activator of the system, i.e. by replacing magnesium or manganese ions. Such an explanation is feasible because staining of bacteria by basic triphenylmethane dyes leads to the displacement of cations such as magnesium ions or hydrogen ions from the cells (McCalla, 1941).

From Table 1 it can be seen that the basic triphenylmethane dyes become more effective as the hydrogen-ion concentration of the system is increased, and in consequence the dyes become more dissociated into cations. Such results are to be compared with those of Quastel \& Yates (1936) concerning the inhibition of saccharase by various basic dyes. They found that the degree of inhibition increased as the hydrogen-ion concentration of the medium decreased. It was suggested that the higher the $\mathrm{pH}$ value, the greater the binding of the dye cations to the negatively charged enzyme protein. The dyes were fully ionized in the experimental conditions employed ( $\mathrm{pH}$ range $3 \cdot 5-6 \cdot 0$ ) and consequently there were no complications concerning the influence of $\mathrm{pH}$ value on the dissociation of the dye.

Arising out of their studies of the staining of bacteria by basic and acidic dyes at various $\mathrm{pH}$ values (Stearn \& Stearn, 1924a), Stearn \& Stearn (1924b) were the first to suggest that the bacteriostatic powers of the basic triphenylmethane dyes were due to the coloured dye cations combining with the acidic groups in the bacterial protein, and that the greater the basicity of the dye, the greater its expected antibacterial action at physiological $\mathrm{pH}$ values. The Stearns, however, also realized that factors other than basicity may influence the absorption of dyes by intact bacteria. Kligler (1918) had already shown that the greater the number of substituent alkyl radicals in the amino groups of the triphenylmethane dyes, the greater the antibacterial activity. An exception was methyl green which, although containing seven methyl groups in the molecule, was virtually inactive. The activity of the basic triphenylmethane dyes in preventing the growth of Streptococcus faecalis and as inhibitors of the internal metabolism of glutamic acid in washed suspensions of the organism was later correlated with the apparent lipid/water partition coefficient of the dyes (Gale \& Mitchell, 1947). This work indicated that the antibacterial properties of these dyes is a reflexion of the ease with which the dyes penetrated the cell walls of the bacteria. Lipid solubility will be influenced by the number and type of the alkyl groups in the dye molecule and since the bacterial plasma-membrane is believed to be composed of lipoprotein (see Mitchell \& Moyle, 1956), it is reasonable to suggest that the greater the lipid solubility of the dye, the greater its antibacterial activity. The apparent partition coefficient between $i$ sobutanol and water for methyl green is very low, and Gale \& Mitchell (1947) therefore concluded that the feeble antibacterial activity of the dye was due to its inability to enter the cell. However, once inside the cell, antibacterial powers of the dyes probably lie in their ability to inhibit one or more essential enzyme systems. The results given in the present paper indicate that as far as glutamine synthesis is concerned, once the basic triphenylmethane dyes have penetrated to the site of action, their effectiveness is related not to their lipid solubility but to their basic dissociation constants. A summary of the known inhibitory effects of the triphenylmethane dyes is 
given in Table 2, in the last three columns of which the figures refer to the dyes arranged in order of increasing activity.

Acetylhydroxamic acid is a compound analogous to glutamylhydroxamic acid and in Escherichia coli the synthesis of the former compound involves the formation of an energy-rich compound, acetyl phosphate, from acetate and

\section{Table 2. Summary of certain properties of basic triphenylmethane dyes}

Sources of data: (a) Goldacre, Phillips \& Rumf (Goldacre \& Phillips, 1949); $(b)$, $(c)$ and $(d)$, Gale \& Mitchell (1947) for Streptococcus faecalis; (e) present paper, synthesis of glutamine by cell-free extracts of Staphylococcus aureus. In columns $(c),(d)$ and $(e)$ numbers refer to position of dyes when placed in order of increasing activity, the larger numbers referring to the higher activities.

\begin{tabular}{|c|c|c|c|c|c|c|}
\hline Dye & $\begin{array}{l}\text { Substituent } \\
\text { groups }\end{array}$ & $\begin{array}{l}\mathrm{pK} \\
(a)\end{array}$ & $\begin{array}{c}\text { Partition } \\
\text { coefficient } \\
\text { butanol/water } \\
(b)\end{array}$ & $\begin{array}{c}\text { Degree of } \\
\text { inhibition } \\
\text { of growth } \\
(c)\end{array}$ & $\begin{array}{l}\text { Degree of inhibi- } \\
\text { tion of glutamate } \\
\text { metabolism; intact } \\
\text { organisms } \\
(d)\end{array}$ & $\begin{array}{l}\text { Degree of inhibi- } \\
\text { tion of glutamine } \\
\text { synthesis; } \\
\text { cell-free extracts } \\
\text { (e) }\end{array}$ \\
\hline Methyl green & $\begin{array}{l}-\mathrm{N}\left(\mathrm{CH}_{3}\right)_{3} \mathrm{Cl} \\
-\mathbf{N}\left(\mathrm{CH}_{3}\right)_{2} \\
-\mathbf{N}\left(\mathrm{CH}_{3}\right)_{2}\end{array}$ & - & $0 \cdot 2$ & 1 & 1 & 4 \\
\hline Fuchsin & $\begin{array}{l}-\mathbf{N H}_{2} \\
-\mathbf{N H}_{2} \\
-\mathbf{N H}_{2} \\
-\mathbf{C H}_{3}\end{array}$ & c. $7 \cdot 0$ & 14.7 & 2 & 2 & 2 \\
\hline Crystal violet & $\begin{array}{l}-\mathbf{N}\left(\mathrm{CH}_{3}\right)_{2} \\
-\mathbf{N}\left(\mathrm{CH}_{3}\right)_{2} \\
-\mathbf{N}\left(\mathrm{CH}_{3}\right)_{2}\end{array}$ & $9 \cdot 4$ & $\begin{array}{c}76 \\
.\end{array}$ & 3 & 3 & 5 \\
\hline Malachite green & $\begin{array}{l}-\mathbf{N}\left(\mathrm{CH}_{3}\right)_{2} \\
-\mathrm{N}\left(\mathrm{CH}_{3}\right)_{2}\end{array}$ & 6.9 & 125 & 4 & 4 & 3 \\
\hline Brilliant green & $\begin{array}{l}-\mathrm{N}\left(\mathrm{C}_{2} \mathrm{H}_{5}\right)_{2} \\
-\mathbf{N}\left(\mathrm{C}_{2} \mathrm{H}_{5}\right)_{2}\end{array}$ & $7 \cdot 9$ & 480 & $\mathbf{5}$ & 5 & 1 \\
\hline
\end{tabular}

ATP and then a spontaneous reaction between the acetyl phosphate and hydroxylamine (Lipmann \& Tuttle, 1945 $a, b$ ). Though the experimental conditions for the synthesis of glutamylhydroxamic acid are similar, an analogous reaction mechanism does not appear to operate since, although crystal violet inhibited the synthesis of glutamylhydroxamic acid, it had no effect on the synthesis of acetylhydroxamic acid (B. A. Fry, unpublished). This supports previous conclusions, since all attempts to show that glutamyl phosphate is an intermediate in glutamine or glutamylhydroxamic acid synthesis have so far failed (Elliott, 1951; Speck, 1949; Fry, 1955).

\section{REFERENCES}

BaIley, K. (1949). The enzymic degradation of adenosinetriphosphate. Biochem. J. 45,479 .

Elliotr, W. H. (1948). Adenosinetriphosphate in glutamine synthesis. Nature, Lond., 161, 128.

Elliotr, W. H. (1951). Studies on the enzymic synthesis of glutamine, Biochem. J. 49, 106.

Elliott, W. H. \& Gale, E. F. (1948). Glutamine-synthesising system of Staphylococcus aureus: its inhibition by crystal violet and methionine-sulphoxide. Nature, Lond. 161, 129. 
Fry, B. A. (1949). The inhibition by triphenylmethane dyes of glutamine synthesis in Staphylococcus aureus. Abstr. 1 st Int. Congr. Biochem. p. 464.

Fry, B. A. (1955). Glutamine synthesis by Micrococcus pyogenes var. aureus. Biochem. J. 59, 579.

Gale, E. F. \& Mitcheil, P. D. (1947). The assimilation of amino-acids by bacteria. 4. The action of triphenylmethane dyes on glutamic acid assimilation. J. gen. Microbiol. 1, 299.

Goldacre, R. J. \& Phillips, J. N. (1949). The ionization of basic triphenylmethane dyes. J. chem. Soc. p. 1724.

Kirby, A. H. M. \& Neubergne, A. (1938). Glyoxalines: the determination of their pK values and the use of their salts as buffers. Biochem. J. 32, 1146 .

Kligler, I. J. (1918). A study of the antiseptic properties of certain organic compounds. J. exp. Med. 27, 463.

KrEBs, H. A. (1935). The metabolism of amino-acids. IV. The synthesis of glutamine from glutamic acid and ammonia, and the enzymic hydrolysis of glutamine in animal tissues. Biochem. J. 29, 1951.

LePAGe, G. A. (1949). In Manometric Techniques and Related Methods for the Study of Tissue Metabolism, 2nd ed. p. 204. Edited by Umbreit, W. W., Burris, R. H. and Stauffer, J. F. Minneapolis: Burgess Publishing Co.

Lewis, G. N., MAgeL, T. T. \& Lipkin, D. (1942). Isomers of crystal violet ion. Their absorption and re-emission of light. J. Amer. chem. Soc. 64, 1774.

Lipmann, F. \& Tuttle, L. C. $(\mathbf{1 9 4 5} a)$. A specific micromethod for the determination of acyl phosphates. J. biol. Chem. 159, 21.

LipmanN, F. \& TUTtLe, L. C. (1945 $b$ ). The detection of activated carbonyl groups with hydroxylamine as interceptor. J. biol. Chem. 161, 415.

McCALLA, T. M. (1941). The reaction of certain stains with bacteria. Stain Tech. 16, 27.

Mickle, H. (1948). Tissue disintegration. J. R. micr. Soc. 68, 10.

Mitcheld, P. \& Moxle, J. (1956). Osmotic function and structure in bacteria. Symp. Soc. gen. Microbiol. 6, 150.

Parnas, J. K. \& Heller, J. (1924). Über den Ammoniakgehalt und über die Ammoniakbildung im Blute. Biochem. Z. 152, 1.

Quastel, J. H. \& YATEs, E. D. (1936). The action of dyestuffs on invertase. Enzymologia, $1,60$.

SPECK, J. F. (1949). The enzymic synthesis of glutamine, a reaction utilizing adenosine triphosphate. J. biol. Chem. 179, 1405.

Stearn, E. W. \& Stearn, A. E. (1924a). The chemical mechanism of bacterial behaviour. 1. Behaviour towards dyes-factors controlling the gram reaction. J. Bact. 9, 463.

Stearn, A. E. \& Stearn, E. W. (1924b). The chemical mechanism of bacterial behaviour. 3. The problem of bacteriostasis. J. Bact. 9, 491.

Vogel, A. I. (1948). Practical Organic Chemistry, 1st ed. p. 851. London: Longmans Green and Co.

(Received 7 September 1956) 